\title{
ANALISIS TUGAS MENULIS KRITIK SASTRA SUNDA DALAM MATA KULIAH KRITIK SASTRA DI JURUSAN PENDIDIKAN BAHASA DAERAH FPBS UPI TAHUN AKADEMIK 2012/2013
}

\author{
Retty Isnendes \\ Jurusan Pendidikan Bahasa Daerah, FPBS UPI \\ Korespondensi: Jln. Dr. Setiabudhi 229 Bandung 40154 \\ Pos-el: chyerettyisnendes@gmail.com
}

\begin{abstract}
Abstrak
Analisis Tugas Menulis Kritik Sastra Sunda dalam Mata Kuliah Kritik Sastra di Jurusan Pendidikan Bahasa Daerah FPBS UPI Tahun Akademik 2012/2013. Tujuan penelitian ini adalah mendeskripsikan: (1) kecenderungan jenis kritik mahasiswa dan (2) kualitas kritik sastra mahasiswa. Metode yang digunakan adalah deskriptif dengan teknik: telaah pustaka, observasi, dokumentasi, dan analisis. Hasil yang didapat adalah sebagai berikut. Kecenderungan jenis kritik yang dipergunakan mahasiswa meliputi jenis tulisan dan jenis isi. Jenis tulisan kritik mahasiswa adalah sastrawan dan akademik, sedangkan jenis isinya adalah intrinsik dan ekstrinsik. Kualitas kritik mahasiswa dengan pola tulisan sastrawan dan akademik adalah: cukup, baik, dan sangat baik nilainya. Adapun kualitas kritik mahasiswa dengan pola tulisan akademik pada kritik tugas kelompok adalah baik dan sangat baik. Saran ditujukan bagi mahasiswa, tim dosen, dan lembaga JPBD.
\end{abstract}

Kata kunci: Tugas, kritik sastra, Jurusan Pendidikan Bahasa Daerah

\begin{abstract}
Writing Task Analysis of Literary Criticism in Literary Criticism in Jurusan Pendidikan Bahasa Daerah FPBS UPI 2012/2013. The purpose of this study is to describe: (1) the tendency of criticism types of students and (2) quality of student literary criticism. The method used is descriptive techniques: literature review, observation, documentation, and analysis. The results are as follows. Tendency kind of criticism that students used include the type of writing and content type. Type of writing is a literary critic and academic students, while it is a kind of intrinsic and extrinsic. Quality of student criticism with literary and academic writing pattern is: pretty, good, and excellent value. As for the criticism of the quality of students with academic writing patterns on group assignments criticism is good and very good. Suggestion is intended for students, faculty teams, and institutions JPBD.
\end{abstract}

Keywords: Assignment, literary criticism, Jurusan Pendidikan Bahasa Daerah

\section{PENDAHULUAN}

Pada studi sastra terdapat tiga wilayah keilmuan, yaitu: sejarah sastra, teori sastra, dan kritik sastra. Tiga wilayah studi ini mempunyai arti dan konsep masing-masing. Teori sastra adalah studi mengenai prinsip, kategori, dan kriteria. Adapun sejarah dan kritik sastra merupakan studi pada karya-karya kongkret (studi terhadap karya sastra) (Wellek \& Warren, 1995:39).

Istilah kritik sastra sudah dikenal sejak tahun 500 SM. Istilah kritik berasal dari kata krinein (Yunani) yang berarti: menghakimi, membandingkan, atau menimbang-nimbang. Kata krinein menjadi pangkal kata kreterion yang berarti: dasar, menimbang-nimbang, atau menghakimi. Orang yang melakukan 
pertimbangan dan penghakiman disebut krites yang berarti hakim.

Kegiatan kritik sastra pertama kali dirintis oleh bangsa Yunani yaitu oleh Xenophanes jeung Heraclitus. Mereka mengkritik bujangga Homerus yang selalu menceritakan dewa-dewa yang dianggap bohong. Setelah itu, kegiatan mengkritik diteruskan oleh Aritophanes, Plato, dan Aristoteles (Semi, 1984:7).

Dari perjalanannya yang panjang, pengertian kritik dalam kegiatan sastra dapat diartikan sebagai penghakiman pada karya sastra. Begitu juga pendapat Wellek, Jassin, dan Hudson yang menyebutkan bahwa kritik sastra adalah penghakiman yang dilakukan oleh seorang yang ahli atau memiliki suatu kepandaian khusus untuk membedah karya sastra, memeriksa karya sastra mengenai kebaikan-kebaikan dan cacat-cacatnya, juga menyatakan pendapatnya tentang hal tersebut (Pradopo, 2002:32). Dengan kata lain, kritik sastra merupakan bidang studi sastra untuk menghakimi karya sastra dan untuk memberi penilaian dan keputusan mengenai bermutu atau tidak suatu karya sastra.

Hakikat kritik sastra adalah adanya analisis, interpretasi, dan evaluasi atau menurut Adams dalam Pradopo (1994:187; 2002:38): interpretasi, analisis, dan penilaian. Ketiga hal tadi erat kaitannya dengan teori sastra atau teori mengenai kritik sastra.

Menurut Wellek \& Warren (1995:41) dalam kritik sastra terdapat tiga aliran penilaian, yaitu absolutisme, relativisme, dan perspektivisme. Selain itu, ada penilaian berdasarkan orientasi pada karya sastra, yaitu: mimetik, pragmatik, ekspresif, dan objektif. Adapun kriteria penilaian terhadap karya sastra berdasarkan pada unsur estetik dan ekstra estetiknya (Wellek \& Warren, 1995:241).

Manfaat atau guna kritik sastra ada tiga macam, yaitu: (1) untuk perkembangan ilmu sastra, (2) untuk perkembangan kesusastraan, dan (3) untuk penerangan masyarakat. Guna yang pertama untuk perkembangan ilmu sastra, penjelasannya adalah: kritik sastra dapat membantu dalam penyusunan teori dan sejarah sastra. Guna yang kedua untuk perkembangan kesusastraan, penjelasannya adalah: kritik sastra dapat membantu perkembangan kesusastraan suatu bangsa dengan menjelaskan baikburuknya karya sastra dan menunjukkan daerah-daerah jangkauan persoalan sastra, juga para sastrawan dapat mengambil manfaat, mereka dapat mengembangkan karya sastra dengan baik. Guna yang ketiga untuk penerangan masyarakat, penjelasannya adalah: kritik sastra dapat menguraikan karya sastra dan masyarakat dapat mengambil manfaat dari kritik sastra bagi pemahaman dan apresiasi terhadap karya sastra (Semi, 1984:24-26).

Pada masyarakat Sunda terdapat sastra Sunda. Sastra Sunda adalah sastra yang berkembang di tatar Sunda yang jenisnya sangat beragam, meliputi sastra lama dan sastra baru. Sastra Sunda adalah bagian dari sastra Nusantara yang merupakan kekayaan batini atau superstruktur Indonesia. Pengklasifikasian sastra Sunda terdiri atas wangun, warna, dan wanda. Wangun adalah klasifikasi berdasarkan perwujudannya (wujud, genre), yaitu puisi, prosa, dan drama. Warna adalah klasifikasi berdasarkan periode terciptanya (waktu), yaitu sastra lama dan sastra baru. Wanda adalah klasifikasi berdasarkan pada media penyampaiannya, yaitu lisan dan tulisan (Iskandarwassid, 1992:138, Koswara 2010:v, Isnendes, 2010:21-22).

Selain karya sastra, studi sastra juga berkembang pada khazanah sastra Sunda walaupun kemajuannya tidak sepesat seperti pada sastra Indonesia, tapi juga tidak stagnan, perbincangan mengenai konsep, sejarah, dan kritik terus bergulir walau riaknya tidak bergelora.

Istilah dan pengertian kritik modern baru dikenal di Tatar Sunda setelah para sastrawan bersentuhan dengan 
pendidikan Barat (terpengaruh), sebagaimana kritik pada konteks Indonesia. Selain itu, setelah adanya gerakan kebangsaan Indonesia yang mempengaruhi sastrawan Sunda dan Indonesia (Rosidi dan Pradopo dalam Isnendes, 2008:3).

Pada sejarah sastra Sunda, kritik adalah hal terlarang. Istilah kritik pada mulanya dibungkus dalam istilah-istilah yang lebih halus, yaitu: pandangan, bahasan, kolom, esay, mutalaah, jrrd. "Kritik" dalam sastra Sunda sangat tertutup, bahkan sampai sekarang. Dalam kegiatan kritik, sebelumnya ada istilah dalam bahasa Sunda yang memberi arti pada kegiatan kritik, yaitu: moyok, nyawad, nyempad, ngawada, ngaruag, nutuh, jrrd yang bersipat destruktif dan negatif (Rosidi dalam Isnendes, 2008:6). Malah dalam kesusastraan Sunda disebutkan bahwa kritik tidak dikenal pada sastra Sunda sebelum perang (Rosidi, 1989:107).

Walaupun demikian, kritik sastra Sunda terus ditulis, sehingga terkumpullah nama-nama kritikus Sunda. Menurut Isnendes (2008:10), tokoh-tokoh kritikus sastra Sunda dengan jenis tulisan sastrawan adalah: Ajip Rosidi, Duduh Durahman, Abdullah Mustappa, Karno Kartadibrata, Usep Romli, Hawe Setiawan, Teddi ANM, juga Bambang Q-Anees. Ada juga kritikus sastra Sunda dengan jenis tulisan sastrawan dan akademik: Yus Rusyana, Teddy Muhtadin, Chye Retty Isnendes, Taufik Ampera, Asep Yusup Hudayat, Darpan, Agus Suherman, Cece Hidayat, dll (bandingkan dengan Hidayat, 2009).

Kritikus-kritikus akademik diprediksi akan semakin banyak karena disediakan wahana pembentuknya: universitas (UPI dan UNPAD). Tetapi kritikus sastrawan semakin surut karena sepertinya kritik sastrawan yang langsung interaksinya dengan penulis kurang disukai, dan dianggap menghakimi. Selain itu, media yang menyediakan halaman untuk itu sangat jarang (kecuali Mangle, Galura, dan Cupumanik --yang kini sudah vakum).

Dalam perkuliahan Kritik Sastra karya-karya sastra Sunda adalah bahan yang demikian kaya untuk dianalisis, diinterpretasi, dan dievaluasi. Demikian juga konsepsi atau teori secara umum, menjadi bahan bagi penulisan kritik sastra Sunda.

Di Jurusan Pendidikan Bahasa Daerah, pada rumpun sastra terdapat mata kuliah studi sastra dan apresiasi sastra. Mata kuliah yang termasuk studi sastra adalah: Sejarah Sastra, Teori Sastra, dan Kritik Sastra yang meliputi genre tradisional dan modern. Mata kuliah Kritik Sastra ini ditawarkan pada semester enam dengan alasan sebagai berikut: (1) mata kuliah lanjutan studi sastra setelah Sejarah Sastra dan Teori Sastra, (2) dianggap mempunyai kesulitan tinggi dibandingkan dengan dua mata kuliah tadi, (3) mahasiswa telah dibekali ilmu tentang perkembangan studi sastra sebagai modal pengalaman menghadapi kesulitan aplikatif.

Tujuan mata kuliah ini, selain mahasiswa mampu menjelaskan konsepkonsep kritik sastra, jenis, metode, aliran, juga harus mampu mengaplikasikannya terhadap karya sastra Sunda. Artinya adalah mahasiswa yang mengontrak mata kuliah ini harus menghasilkan tulisan kritik terhadap sastra Sunda.

Menghadapi tugas menulis kritik, mahasiswa dianggap kesulitan karena harus mengekspresikan pemikirannya secara mahir dan terstruktur tulis. Selain itu, mahasiswa memandang sedikit hasil karya kritik yang bisa dijadikan contoh. Jikapun ada, buku teksnya sulit dicari dan sudah tidak dicetak lagi (kecuali bukubuku Ajip Rosidi yang diterbitkan lagi oleh Kiblat Buku Utama). Dengan demikian motivasi mahasiswa menulis kritik sastra menjadi kecil dan kurang.

Pencapaian tujuan menulis kritik sastra selama ini belum dianalisis secara 
mendalam bagaimana hasil para mahasiswa yang mengontak mata kuliah Kritik Sastra. Apakah pencapaian merujuk pada ukuran tertentu atau tidak, hanya dirumuskan dalam pikiran pengajar (dosen) dan langsung dituliskan hasil akhirnya dalam bentuk bilangan: 4, 3, 2, atau dalam bentuk abjad: A, B, C.

Melalui penelitian ini, hasil menulis kritik sastra Sunda pada mata kuliah Kritik Sastra bisa tergambar dengan nyata melalui ukuran-ukuran yang ditetapkan. Adapun tujuan penelitian ini adalah menjawab rumusan mengenai: (1) kecenderungan jenis kritik sastra mahasiswa dan (2) kualitas kritik sastra mahasiswa.

\section{METODE}

Metode yang digunakan adalah kualitatif. Teknik yang digunakan dalam penelitian ini adalah: (1) telaah pustaka, (2) observasi, (3) teknik dokumentasi, (4) teknik analisis. Lembar analisis (lembar kemampuan personal jenis kritik menurut isinya dan jenis kritik menurut tulisannya; skala penilaian kualitas kritik) dan lembar ceklis digunakan sebagai instumen.

Instrumen penelitian ini disusun berdasarkan pada pendapat Wellek dan Warren tentang jenis kritik sastra, yaitu intrinsik dan ekstrinsik (Sukada, 1993:5058). Kritik sastra intrinsik berpegang pada: (1) kegiatan analisisnya berdasarkan pada jenis dan gaya, (2) membandingkan genre satu dengan yang lainnya, (3) mengkaji unsur-unsur karya, (4) memberi penilaian dan kesimpulan nilai positif-negatif dari sebuah karya. Kritik sastra ekstrinsik berpegang pada: (1) hubungan karya dan penulisnya, (2) hubungan karya dengan pembacanya, (3) mengkaji hal-hal di luar karya, (4) melibatkan disiplin ilmu: antropologi, sejarah, agama, filsafat, dll.

Demikian juga dengan jenis kritik sastra. Berdasarkan sifat dan asal kritikusnya adalah kritik jenis sastrawan (dengan bentuk penulisan non-ilmiah) dan kritik jenis akademik (dengan bentuk penulisan ilmiah). Ciri-ciri bentuk ini mengacu pada bentuk atau pola penulisan. Biasanya sastrawan menulis karya kritiknya dengan cara artikel populer, sedangkan akademisi menulis karya kritiknya dengan cara sistematika formal dan mencirikan karya tulis ilmiah dalam bentuk: makalah, skripsi, tesis, disertasi, laporan atau artikel ilmiah (Pradopo, 1994:99-100; 2002:363-373).

Tujuan penulisan kritik sastra adalah sebagai: (1) impresionistik, (2) penghakiman (Pradopo, 1994:24-25) dan (3) teknis. Impresionistik berupa kesan pribadi yang bernilai subjektif. Penghakiman penilaian yang bergantung pada hukum-hukum tertentu. Teknis adalah tujuan kritikus menunjukkan kekurangan-kekurangan karangan pada pengarang, dan diharapkan pengarang belajar dari kekurangan tersebut untuk karya di kemudian hari.

Tabel 1

Instrumen Penilaian Kualitas Kritik Mahasiswa

\begin{tabular}{|c|l|c|c|}
\hline No & \multicolumn{1}{|c|}{ Aspek yang dinilai } & $\begin{array}{c}\text { Skor } \\
\text { Maksimum }\end{array}$ & $\begin{array}{c}\text { Skor } \\
\text { Mahasiswa }\end{array}$ \\
\hline 1. & Isi (gagasan yang diekspresikan) & 35 & \\
\hline 2. & $\begin{array}{l}\text { Organisasi Isi } \\
\text { (Kaya: imajinasi, logika isi, kasinambungan antar } \\
\text { paragraf, kepaduan isi) }\end{array}$ & 25 & \\
\hline 3. & Tata bahasa & 25 & \\
\hline 4. & Gaya: pilihan struktur dan kekayaan kata & 15 & \\
\hline 5. & Ejaan & 5 & \\
\hline 6. & Jumlah Skor & 100 & \\
\hline
\end{tabular}


Tabel 2

Instrumen Kemampuan Individu Menulis Kritik Sastra Berdasarkan Jenis Pola Tulisan

\begin{tabular}{|c|c|c|c|c|c|}
\hline \multirow[t]{3}{*}{ No } & \multicolumn{2}{|c|}{ Materi Kritik Menurut Pola Tulisannya } & \multirow{2}{*}{\multicolumn{3}{|c|}{$\begin{array}{c}\text { Kemampuan } \\
\text { Personal }\end{array}$}} \\
\hline & \multirow[t]{2}{*}{ Jenis } & \multirow[t]{2}{*}{ Kriteria Isi } & & & \\
\hline & & & 1 & 2 & 3 \\
\hline 1 & \multirow{8}{*}{ Sastrawan } & Ditulis oleh kritikus atau umum & & & \\
\hline 2 & & $\begin{array}{l}\text { Berwujud artikel populer atau esai-esai } \\
\text { yang bisa dikirimkan ke media massa }\end{array}$ & & & \\
\hline 3 & & Teknik tulisan tidak berpola TPI & & & \\
\hline 4 & & Tidak perlu refensi akurat & & & \\
\hline 5 & & Teori \& metode tidak eksplisit & & & \\
\hline 6 & & Sifat tulisan ekspresif & & & \\
\hline 7 & & Tinjauan impresionistik & & & \\
\hline 8 & & Bahasa populer & & & \\
\hline 1 & \multirow{7}{*}{ Akademik } & Kritikus berlatar pendidikan sastra & & & \\
\hline 2 & & $\begin{array}{l}\text { Kritikan berwujud artikel ilmiah atau } \\
\text { makalah ilmiah }\end{array}$ & & & \\
\hline 3 & & $\begin{array}{l}\text { Kritikan ditulis dalam teknik penulisan } \\
\text { ilmiah (TPI) }\end{array}$ & & & \\
\hline 4 & & Metode deduktif dan induktif & & & \\
\hline 5 & & Bersifat analitik, merenik; mendetail & & & \\
\hline 6 & & $\begin{array}{l}\text { Tinjauan pustaka; daftar pustakanya } \\
\text { ditulis sebagai sumber rujukan }\end{array}$ & & & \\
\hline 7 & & Bahasa baku dan ilmiah & & & \\
\hline
\end{tabular}

Tabel 3

Instrumen Kemampuan Individu Menulis Kritik Sastra Berdasarkan Jenis Isi Tulisan

\begin{tabular}{|c|c|c|c|c|c|}
\hline \multirow[t]{3}{*}{ No } & \multicolumn{2}{|c|}{ Materi Jenis Kritik Menurut Isinya } & \multirow{2}{*}{\multicolumn{3}{|c|}{$\begin{array}{c}\text { Kemampuan } \\
\text { Individual }\end{array}$}} \\
\hline & \multirow[t]{2}{*}{ Jenis } & \multirow[t]{2}{*}{ Kriteria Isi } & & & \\
\hline & & & 1 & 2 & 3 \\
\hline 1 & \multirow{4}{*}{ Intrinsik } & Berdasarkan jenis dan gaya & & & \\
\hline 2 & & $\begin{array}{l}\text { Membandingkan genre satu dengan } \\
\text { yang lainnya, }\end{array}$ & & & \\
\hline 3 & & Mengkaji unsur-unsur karya, & & & \\
\hline 4 & & $\begin{array}{l}\text { Memberi penilaian dan kesimpulan nilai } \\
\text { positif-negatif dari sebuah karya. }\end{array}$ & & & \\
\hline 1 & \multirow[t]{4}{*}{ Ekstrinsik } & $\begin{array}{l}\text { Menghubungkan karya dengan } \\
\text { penulisnya }\end{array}$ & & & \\
\hline 2 & & $\begin{array}{l}\text { Menghubungkan karya dengan } \\
\text { pembacanya }\end{array}$ & & & \\
\hline 3 & & Mengkaji hal-hal di luar karya, & & & \\
\hline 4 & & $\begin{array}{l}\text { Melibatkan disiplin ilmu: antropologi, } \\
\text { sejarah, agama, filsafat, dll. }\end{array}$ & & & \\
\hline
\end{tabular}


Sumber data dalam penelitian ini adalah hasil dari tugas menulis kritik pada karya sastra Sunda dari seluruh mahasiswa kelas A Kritik Sastra. Karakter mahasiswa pada Semester 6 tahun akademik 2012/2013 unik dan beragam kemampuannya tetapi tetap pada proporsi pembelajar yang konvesional.

\section{HASIL DAN PEMBAHASAN}

Dari hasil pembelajaran dan tugas yang diberikan pada 41 mahasiswa di Kelas A tahun akademik 2012/2013, terkumpul $41 \mathrm{kritik}$ pada karya cerita pendek Sunda 'carpon', 40 kritik pada karya genre puisi (mantra, pupujian, dan sajak Sunda modern), dan lima makalah diskusi yang mengurai aliran kritik, tokoh, dan penerapan kritik dari sudut pandang aliran kritik sastra tersebut.

\section{Kecenderungan Jenis Kritik Mahasiswa Jenis Kritik Berdasarkan pada Pola Tulisan: Sastrawan-Akademik}

Melalui kriteria yang juga dijadikan instrumen dalam penelitian ini,

terdapat hasil yang merupakan kecenderungan kemampuan mahasiswa dalam menulis kritik. Jenis kritik yang dipilih oleh mahasiswa dibagi dalam tiga kategori, yaitu: (1) jenis kritik pada carpon 'cerpen' yang dibuat oleh mahasiswa secara individual berdasarkan pada jenis pola tulisan kritik sastrawan, (2) jenis kritik pada puisi yang dibuat oleh mahasiswa secara individual berdasarkan pada jenis pola tulisan kritik akademik, dan (3) jenis kritik pada genre pilihan secara kelompok berdasarkan pada jenis pola tulisan akademik.

Jenis kritik pada carpon 'cerpen' yang dibuat oleh mahasiswa secara individual berdasarkan pada jenis pola tulisan kritik sastrawan dengan tingkat kemampuan personal yang bermacammacam, keseluruhannya dianggap cukup dan baik. Dengan penilaian berdasarkan pada delapan kriteria jenis kritik sastrawan dan tiga tingkat kemampuan personal, jumlah ideal yang didapat adalah 24. Nilai 16-17 dianggap cukup dan nilai 18, 19, 20, dianggap baik dalam memenuhi kriteria.

Tabel 4

Kemampuan Individu Mahasiswa Menulis Kritik Sastrawan

\begin{tabular}{|c|c|c|c|c|}
\hline No & $\begin{array}{c}\text { Jumlah } \\
\text { Mahasiswa }\end{array}$ & Bobot & Persentase & Nilai \\
\hline 1 & 2 & 16 & $4,9 \%$ & Cukup \\
\hline 2 & 11 & 17 & $26,8 \%$ & Cukup \\
\hline 3 & 17 & 18 & $41,5 \%$ & Baik \\
\hline 4 & 3 & 19 & $7,3 \%$ & Baik \\
\hline 5 & 8 & 20 & $19,5 \%$ & Baik \\
\hline Jml & 41 & Jumlah & $\mathbf{1 0 0 \%}$ & \\
\hline
\end{tabular}

jenis kritik pada puisi Sunda (mantra, pupujian, dan sajak modern) yang dibuat oleh para mahasiswa berdasarkan pada pola tulisan kritik akademik dengan tingkat kemampuan personal yang bermacam-macam, keseluruhannya juga dianggap cukup dan baik. Dengan penilaian berdasarkan pada delapan kriteria jenis kritik akademik dan tiga 
tingkat kemampuan personal, jumlah ideal yang didapat adalah 24. Nilai 16-17 dianggap cukup dan nilai 18, 19, 20, dianggap baik dalam memenuhi kriteria, sedang nilai 10 adalah tidak berhasil karena mahasiswa salah menerapkan jenis tulisan kritik, dan nilai 0 adalah gagal.

Tabel 5

Kemampuan Individu Mahasiswa Menulis Kritik Akademik

\begin{tabular}{|c|c|c|c|c|}
\hline No & $\begin{array}{c}\text { Jumlah } \\
\text { Mahasiswa }\end{array}$ & Bobot & Persentasi & Nilai \\
\hline 1 & 1 & 0 & $2,44 \%$ & Gagal \\
\hline 2 & 2 & 10 & $4,88 \%$ & Tak Berhasil \\
\hline 3 & 13 & 17 & $31,71 \%$ & Cukup \\
\hline 4 & 18 & 18 & $43,90 \%$ & Baik \\
\hline 5 & 1 & 19 & $2,44 \%$ & Baik \\
\hline 6 & 6 & 20 & $14,63 \%$ & Baik \\
\hline Jml & 41 & Jml & $100 \%$ & \\
\hline
\end{tabular}

Adapun kritik pada genre karya sastra sebagai objek pilihan tugas kelompok (sajak, carpon, dan naskah drama) dengan sudut pandang kelompok bertumpu aliran kritik sastra (Merlyn, New
Criticsm, Nouvelle Critique, Feminisme, dan Dekonstruksi) adalah cukup dan baik. Nilai 17 dianggap cukup dan nilai 18 dianggap baik.

\section{Tabel 6}

Kemampuan Kelompok Mahasiswa Menulis Kritik Sastra Berdasarkan Aliran

\begin{tabular}{|c|c|c|c|c|}
\hline No & Kelompok & Bobot & Persentase & Nilai \\
\hline 1 & Nouvelle Critique & 17 & $20 \%$ & Cukup \\
\hline 2 & Merlyn & 18 & & Baik \\
\cline { 1 - 2 } 3 & New Criticsm & 18 & \multirow{2}{*}{$80 \%$} & Baik \\
\cline { 1 - 2 } & Feminisme & 18 & & Baik \\
\hline 5 & Dekonstruksi & 18 & & Baik \\
\hline Jml & Lima Kelompok & Jml & $\mathbf{1 0 0 \%}$ & \\
\hline
\end{tabular}


Jenis Kritik Berdasarkan pada Isi: Instrinsik-Ekstrinsik

Menentukan jenis kritik ini bertumpu pada gaya pemilihan isi, yaitu intrinsik (menitikberatkan pada unsurunsur dalam kritik) atau ekstrinsik (menitikberatkan pada unsur-unsur luar kritik). Unsur-unsur dalam dan luar tersebut adalah ciri-ciri tulisan intrinsik atau ekstrinsik yang dibuat menjadi kriteria penulisan jenis isi. Kriteria menentukan jenis isi tersebut berjumlah empat butir (lihat istrumen).

Berdasarkan hasil analisis, jenis isi kritik sastrawan pada carpon 'cerpen' yang ditulis mahasiswa adalah intrinsik dan estrinsik. Jenis kritik intrinsik berjumlah $65,85 \%$ atau terdapat 27 buah tugas kritik mahasiswa berjenis kritik intrisik, sedangkan $34,15 \%$ atau 14 tugas kritik mahasiswa berjenis intrinsikekstrinsik (campuran). Berdasarkan hasil analisis, kritik mahasiswa pada puisi, dengan jenis pola tulisan akademik, 61\% atau 25 tugas kritik mahasiswa isinya berjenis intrisik, sedangkan, 39\% atau 16 tugas kritik mahasiswa isinya berjenis intrisik-ekstrinsik (campuran). Demikian juga dengan pada kritik puisi mahasiswa dengan jenis pola tulisan akademik, $80 \%$ atau 4 tugas kritik mahasiswa berjenis intrisik, sedangkan, $20 \%$ atau 1 tugas kritik mahasiswa isinya berjenis intrisikekstrinsik (campuran).

\section{Kualitas Kritik Sastra Mahasiswa}

Kualitas tugas kritik sastra mahasiswa dengan pola kritik sastrawan pada carpon 'cerpen', pola kritik akademik pada puisi, dan pola akademik pada genre pilihan dalam kelompok dinilai berdasarkan lima kriteria dengan jumlah skor keseluruhan adalah 100.

Kriteria kualitas isi atau gagasan yang diekspresikan, rata-rata dalam rentang nilai 20-30 dari nilai ideal 35 . Organisasi isi, yaitu kekayaan imajinasi, logika, kesinambungan antar paragraf, dan kepaduan isi rata-rata berada pada rentang nilai $16-22$ dari nilai ideal 25 . Kriteria tata bahasa rata-rata berada pada rentang nilai 16-22 dari nilai ideal. Kriteria gaya, yaitu pilihan struktur dan kekayaan kata ratarata 7-12 dari nilai ideal 15. Adapun kriteria ejaan rata-rata 3-5 dari nilai ideal 5.

Kualitas tugas kritik mahasiswa dengan pola sastrawan pada carpon 'cerpen' adalah cukup, baik, dan sangat baik, dan diasumsikan ada yang bisa dikirimkan ke media Sunda dan ada yang layak dimuat pada media Sunda. Hal yang perlu diperhatikan bila akan dimuatkan pada media Sunda adalah jenis pemilihan objek analisis, yaitu harus harus merupakan karya baru terbit atau setidaknya terbit pada 1-2 tahun terakhir, sedangkan yang menjadi objek penelitian adalah cerita pendek yang sudah ada, bahkan kadaluarsa bila dalam ukuran kebaruan terbit. 
Tabel 7

Kualitas Individu Kritik Sastrawan pada Carpon 'Cerpen'

\begin{tabular}{|c|c|c|c|c|}
\hline No & $\begin{array}{c}\text { Jumlah } \\
\text { Mahasiswa }\end{array}$ & Bobot & Persentase & Nilai \\
\hline 1 & 1 & 64 & $2,44 \%$ & Cukup \\
\hline 2 & 6 & 65 & $14,63 \%$ & Cukup \\
\hline 3 & 1 & 66 & $2,44 \%$ & Cukup \\
\hline 4 & 2 & 68 & $4,88 \%$ & Cukup \\
\hline 5 & 12 & 70 & $29,27 \%$ & Baik \\
\hline 6 & 2 & 72 & $4,88 \%$ & Baik \\
\hline 7 & 10 & 75 & $24,39 \%$ & Baik \\
\hline 8 & 2 & 80 & $4,88 \%$ & Baik \\
\hline 9 & 2 & 85 & $4,88 \%$ & Sangat Baik \\
\hline 10 & 3 & 88 & $7,31 \%$ & Sangat baik \\
\hline 11 & 41 & JUMLAH & $\mathbf{1 0 0 \%}$ & \\
\hline
\end{tabular}

Kualitas tugas kritik mahasiswa dengan pola kritik akademik pada puisi dinilai cukup, baik, dan sangat baik, walaupun ada yang tak berhasil (1 orang) karena tugas tidak dibuat.

Tabel 8

Kualitas Individu Kritik Akademik pada Puisi

\begin{tabular}{|c|c|c|c|c|}
\hline No & $\begin{array}{c}\text { Jumlah } \\
\text { Mahasiswa }\end{array}$ & Bobot & Persentasi & Nilai \\
\hline 1 & 1 & 0 & $2,44 \%$ & Gagal \\
\hline 2 & 6 & 65 & $14,63 \%$ & Cukup \\
\hline 3 & 4 & 66 & $9,75 \%$ & Cukup \\
\hline 4 & 4 & 67 & $9,75 \%$ & Cukup \\
\hline 5 & 1 & 68 & $2,44 \%$ & Cukup \\
\hline 6 & 4 & 69 & $9,75 \%$ & Cukup \\
\hline 7 & 6 & 70 & $14,63 \%$ & Baik \\
\hline 8 & 1 & 72 & $2,44 \%$ & Baik \\
\hline 9 & 7 & 75 & $17,01 \%$ & Baik \\
\hline
\end{tabular}




\begin{tabular}{|c|c|c|c|c|}
\hline 10 & 4 & 80 & $9,75 \%$ & Baik \\
\hline 11 & 2 & 87 & $4,88 \%$ & Sangat Baik \\
\hline 12 & 1 & 88 & $2,44 \%$ & Sangat Baik \\
\hline 13 & 41 & JUMLAH & $\mathbf{1 0 0 \%}$ & \\
\hline
\end{tabular}

Adapun kualitas tugas kritik kelompok mahasiswa dengan pola kritik akademik pada genre karya pilihan dinilai cukup, baik,dan sangat baik, walaupun pada analisis belum berkembang dan belum digali kedalaman analis, tapsiran, dan evaluasinya mengenai karya sesuai dengan sudut pandang aliran yang dipilihnya.

\section{Tabel 9}

Kualitas Menulis Kritik Sastra Kelompok Berdasarkan pada Aliran Kritik Sastra

\begin{tabular}{|c|c|c|c|c|}
\hline No & Kelompok & Bobot & Persentase & Nilai \\
\hline 1 & Merlyn & 75 & $20 \%$ & Cukup \\
\hline 2 & New Criticsm & 82 & \multirow{2}{*}{$40 \%$} & Baik \\
\hline 3 & Nouvelle Critique & 82 & & Baik \\
\hline 4 & Feminisme & 88 & $20 \%$ & Sangat Baik \\
\hline 5 & Dekonstruksi & 81 & $20 \%$ & Baik \\
\hline 6 & JUMLAH & $\mathbf{5}$ & $\mathbf{1 0 0} \%$ & \\
\hline
\end{tabular}

\section{SIMPULAN DAN SARAN}

Kecenderungan jenis kritik yang dipergunakan mahasiswa meliputi jenis tulisan dan jenis isi. Jenis tulisan kritik mahasiswa adalah sastrawan dan akademik, sedangkan jenis isinya adalah intrinsik dan ekstrinsik. Pada jenis pola tulisan sastrawan, karya kritik mahasiswa dianggap layak dan baik. Layak artinya bisa dikirimkan pada media Sunda, dan yang sudah baik dianggap dapat dimuat pada media Sunda, yang tentu saja melalui editorial media.

Keberhasilan pola tulisan sastrawan dianggap bisa dibuat oleh umum dan calon kritikus karena berbentuk esai yang paradigma berpikirnya mengikuti pola pikir penulisnya dan tidak terikat pada ketentuan-ketentuan khusus (ilmiah). Kekurangannya adalah kurangnya faktor interpretasi dan evaluasi. Pada jenis pola tulisan akademik adalah cukup dan baik, dengan kekurangan yang kurang merenik dan keseimbangan antara teori dan analisis belum berimbang. Kualitas kritik mahasiswa dengan pola tulisan sastrawan dan akademik adalah: cukup, baik, dan sangat baik nilainya. Adapun kualitas kritik mahasiswa dengan pola tulisan akademik pada kritik tugas kelompok adalah cukup, baik, dan sangat baik. Saran ditujukan pada: mahasiswa, tim dosen, dan lembaga JPBD. 


\section{UCAPAN TERIMA KASIH}

Ucapan terima kasih disampaikan pada Jurusan Pendidikan Bahasa Daerah FPBS UPI Bandung yang telah mendanai penelitian ini, kepada Dr. Ruswendi Permana, M.Hum sebagai anggota penelitian dan mahasiswa semester enam tahun ajaran 2012/2013. Tak lupa ucapan terima kasih disampaikan kepada Prof. Dr. Didi Sukyadi, M.A. dan Dr. Dedi Koswara, M.Hum yang telah memeriksa artikel ini.

\section{PUSTAKA RUJUKAN}

Hidayat, C.2009. "Esai jeung Kritik tina Kasusastraan Sunda" dalam Cahara Bumi Siliwangi No. 3 Bulan Oktober 2009. Bandung: Sonagar Press.

Iskandarwassid. 1992. Kamus Istilah Sastra. Bandung: CV. Geger Sunten.

Isnendes, R. 2008. "Panyawangan Sastra: Hand-out Perkuliahan Kritik Sastra" (Makalah). Bandung: JPBD FPBS UPI.

2010. Kajian Sastra: Aplikasi Teori dan Kritik pada Karya Sastra Sunda dan Indonesia. Bandung: Daluang Press.

.2010. Teori Sastra. Bandung: JPBD FPBS UPI.

Koswara, D. 2010. Sastra Sunda Buhun. Bandung: JPBD FPBS UPI.

Pradopo, R, Dj. 1994. Prinsip-prinsip Kritik Sastra. Yogyakarta: Gadjah Mada University Press.

.2002. Kritik Sastra Indonesia Modern. Yogyakarta: Gama Media.

Rosidi, A. 1989. Beber Layar!. Jakarta: PT. Girimukti Pasaka.
Semi, A. 1984. Kritik Sastra. Bandung: Angkasa.

Sukada, M. 1993. Pembinaan Kritik Sasta Indonesia: Masalah Sistematika Analisis Struktur Fiksi. Bandung: Angkasa.

Wellek, R dan Warren, A. 1995. Teori Kesusastraan. Jakarta: Gramedia.

Blog: http://chyeretty.wordpress.com 